\title{
Gene Expression Patterns of Bone Morphogenetic Proteins (BMPs) During Early Embryonic Development in The Annual Killifish Austrofundulus Limnaeus
}

Eva Y. Chan

Portland State University

Follow this and additional works at: https://pdxscholar.library.pdx.edu/mcnair

Part of the Biology Commons

Let us know how access to this document benefits you.

\section{Recommended Citation}

Chan, Eva Y. (2016) "Gene Expression Patterns of Bone Morphogenetic Proteins (BMPs) During Early Embryonic Development in The Annual Killifish Austrofundulus Limnaeus," PSU McNair Scholars Online Journal: Vol. 10: Iss. 1, Article 3.

https://doi.org/10.15760/mcnair.2016.2

This open access Article is distributed under the terms of the Creative Commons Attribution-NonCommercialShareAlike 4.0 International License (CC BY-NC-SA 4.0). All documents in PDXScholar should meet accessibility standards. If we can make this document more accessible to you, contact our team. 
Gene Expression Patterns of Bone Morphogenetic Proteins (BMPs) During Early Embryonic Development in The Annual Killifish Austrofundulus Limnaeus

By

\section{Eva Y. Chan}

Faculty Mentor: Jason E. Podrabsky, Ph.D.

Citation: Chan, E. Y. and Podrabsky, J. E. Gene Expression Patterns of Bone Morphogenetic Proteins (BMPs) During Early Embryonic Development in The Annual Killifish Austrofundulus Limnaeus. Portland State University McNair Scholars Online Journal, Vol. 10, Year: 2016. 


\section{Abstract}

The developmental pattern of the annual killifish Austrofundulus limnaeus is unusual compared to other fish. First, the cell movements associated with gastrulation are separated from formation of the embryonic axis. In addition, embryonic diapause can occur. Diapause II and III are often observed when embryos are incubated at $25^{\circ} \mathrm{C}$. Maternal influences and incubation environment are the factors that determine entrance into embryonic diapause, but the molecular mechanisms that regulate diapause are still unknown. Interestingly, embryonic diapause and the unusual cell movements observed during early development are always found together in species of annual killifish that exhibit diapause. Bone morphogenetic proteins (BMPS) are crucial in the development of various embryonic tissues. A recent study found the gene expressions pattern of BMP antagonists, noggin, chordin and follistatin, in early - embryonic development in $A$.

limnaeus are different from zebrafish. This finding suggests BMPs may play roles in the regulation of diapause. In the present paper, the expression of BMP-2, BMP-4 and the BMP Receptor-2 were examined during early embryonic development in $A$. limnaeus using reverse transcription polymerase chain reaction (RT-PCR).

Keywords: Austrofundulus Limnaeus, gene expression, embryonic development, diapause, bone morphogenetic proteins (BMPs), BMP antagonists 


\section{Introduction}

The analysis of hibernation and diapause among animals may provide information or shed light upon the fundamental cellular activities of multicellular organisms as well as how environmental conditions influence embryonic development in certain organisms. Annual killifish inhabit seasonal ponds in areas of Africa and South America. Several hundred species in this group rely on embryonic diapause to survive the drought season (Murphy and Collier, 1997). Diapause appears to have evolved separately on the two continents, Africa and South America. Amazingly, all annual killifish exhibit similar developmental stages, diapause I, II and III, where embryos can enter reversible metabolic and developmental arrest (Wourms, 1972a; Wourms, 1972b; Wourms,1972c). This striking example of convergent evolution of embryonic diapause in annual killifish was possibly driven by their harsh habitat.

The annual killifish Austrofundulus limnaeus inhabits seasonal ponds in regions of northern Venezuela (Podrabsky et al., 1998; Hrbek et al., 2005). Compared to other teleosts, embryonic development of $A$. limnaeus is highly variable. Most embryos of this species can enter diapause II and III when reared in the lab and incubated at $25^{\circ} \mathrm{C}$ in the dark. Only a small percentage of embryos escape diapause II and develop continuously and enter diapause III (Podrabsky and Hand, 1999). Both maternal influence and the incubation environment experienced by the embryo can determine if an embryo will enter diapause II. A higher proportion of escape embryos are produced by young females and incubation temperatures of $30^{\circ} \mathrm{C}$ favors development of escape embryos. The early produced embryos might have sufficient time to complete their lifecycle before the dry season, so it makes sense that young females produce more escape embryos than the old females (Podrabsky et al., 2010). Escape embryos follow a different developmental pathway- their anterior and development is advanced compared to posterior development when compared with those entering diapause II (Podrabsky et al., 2010). This completely different form of early developmental plasticity within the same species is rarely observed in vertebrate embryos. Hence, the divergence in early development of $A$. limnaeus seems to be a novel phenomenon. The developmental trajectory in this system seems regulated by maternal influences, but it can be overridden by increasing the incubation temperature to $30^{\circ} \mathrm{C}$ (Podrabsky et al., 2010). Apart from the environmental insult that lead to metabolic arrest in $A$. limnaeus, recent research done in the Podrabsky lab has indicated that bone morphogenetic proteins (BMPs) may play critical roles in the regulation of diapause (Wagner and Podrabsky, 2015).

Like their name suggests, BMPs are important in bone and cartilage development. In addition, they also play crucial roles in the formation and differentiation of the nervous system in vertebrates (Liu and Niswander, 2005). BMPs are a group of multifunctional growth factors that belong to TGF $\beta$ protein family and are known to be important in vertebrate embryo development. Smad 1, 5 and 8 are the pivotal intracellular effectors of BMPs and they play crucial roles in BMP signal transduction. (Chen et al., 2004; Winnier et al., 2005; Nikaido et al., 1997; Larrain et al., 2000; Liu and Niswander, 2005; von der Hardt et al., 2007). BMP extracellular ligands bind to the BMP receptors (BMPR1 and BMPR2), which belong to a family of transmembrane serine -threonine kinases, then phosphorylate receptor-activated Smad proteins (R-Smads). The activated R-Smad associates with common mediator (co-Smad) and then the complex enters the nucleus to regulate gene expression (Liu and Niswander, 2005). Noggin, chordin and follistatin are extracellular BMP antagonists (Wagner and Podrabsky, 2015), which bind directly to BMP ligands preventing them from binding with their cognate receptors and thus blocking the BMP signaling pathway (Liu and Niswander 2005). Mutations in BMPs and related genes affects the development of heart, neuron and cartilage in animals and humans (Chen at el., 2004). The correct formation of dorsal-ventral (DV) patterning in vertebrate embryos is controlled by signaling gradients of BMPs and their interaction with secreted BMP antagonists by the Spemann-Mangold Organizer (Wagner and Podrabsky, 2015). 
A recent study in the expression of DV patterning genes during early development in $A$. limnaeus found that gene expression patterns of chordin and noggin-1 were different from zebrafish embryos. High expression of chordin and noggin-1 were detected in early cleavage stage embryos, right after fertilization, indicating maternally packaged chordin and noggin-1 may have unique function in early embryonic development in A. limnaeus (Wagner and Podrabsky 2015). Another study revealed three BMP genes in zebrafish (zBMPs) embryos, BMP-2a, BMP-2b and BMP-4, were expressed in 4, 8, 11, and 36 hours after fertilization (Martinez - Barbera, 1997). Human, mouse, Xenopus, and zebrafish BMP-2 and BMP-4 share a conserved sequence motif (Nikaido et al., 1997). BMP-2 may play a role in early embryo patterning and organogenesis in zebrafish (Nikaido et al., 1997). A comparison of zebrafish BMP-2 expression pattern with a fate map (Kimmel et al., 1990) showed zebrafish BMP-2 may act as a neural inhibitor, similar to Xenopus BMP-4 and Drosophila BMP (De Robertis and Sasai, 1996). Though the function of zBMP-4 is unknown, it can be deduced that zBMP-4 might have a similar role to anti-dorsalizing morphogenetic protein (Moos et al., 1995). Noggin is known to be a repressor of BMP-4 expression in the ventral marginal zone (Re'em-Kalma et al., 1995). Probably, noggin represses zBMP-2 expression in mesoderm (Nikaido et al. 1997). Therefore, it would be interesting to see the gene expressions of BMPs and BMP receptors in $A$. limnaeus embryos that will enter diapause compared to those that will not (called escape embryos), because the timing of development are different in these two groups of embryos (Podrabsky et al., 2010). In the present paper, four early - developmental stages (prior to diapause II) of $A$. limnaeus embryos were examined. Based on the above findings, it is possible to hypothesize that the gene expression of BMP-2 would be high right after early cleavage stage in $A$. limnaeus embryos while the gene expression of BMP-4 would be relatively low.

\section{Materials and Methods}

\section{Husbandry of adult fish and treatment of embryos}

Adult Austrofundulus limnaeus (Schultz 1949) were reared in the aquatic vertebrate facility at Portland State University. Embryos were collected 2 hours after mating. Randomly selected mating pairs of fish were allowed to deposit eggs into trays of glass beads (Thomas Scientific, Swedesboro, NJ, USA). Fertilized eggs were separated from unfertilized ones using a dissecting microscope by removing eggs without a clear perivitelline space. Fertilized eggs were transferred and incubated in a medium with similar ionic composition of their native ponds $(0.0013 \mathrm{mM} \mathrm{MgSO} 4,0.14 \mathrm{mM} \mathrm{KCl}$, $0.8 \mathrm{mM} \mathrm{CaCl} 2,2.14 \mathrm{mM} \mathrm{MgCl} 2,10 \mathrm{mM} \mathrm{NaCl})$. Methylene blue $(0.001 \%)$ was added to the medium to help prevent fungal infections (Podrabsky et al.,1998; Podrabsky, 1999). The medium was changed daily for the duration of the experiment.

\section{Embryonic Stages Examined}

Four different early developmental stages of embryos were examined: early cleavage (1-4 hours post fertilization, hpf), high solid blastula ( $24 \mathrm{hpf}$ ), flat solid blastula (36 hpf), and 25\% epiboly (48 hpf). For each stage, 4 replicates of 50 embryos were collected and placed into $2 \mathrm{ml}$ microcentrifuge tubes ( 50 embryos for each tube). Embryos were then flash-frozen by submersion in liquid nitrogen and stored at $-80^{\circ} \mathrm{C}$ until RNA extractions were performed.

\section{Isolation of Total RNA}

TRIzol reagent (Life Technologies) was used to maintain RNA integrity during purification. Embryos were homogenized by the addition of $1 \mathrm{ml}$ TRIzol directly into the $2 \mathrm{ml}$ microcentrifuge tube that contained 50 frozen embryos, followed immediately by 20-30 sec of homogenization using an IKA Ultraturax dispersion homogenizer at the highest setting. Homogenates were kept at room 
temperature for 10-15 minutes to allow complete dissociation of nucleoprotein complexes. Homogenates were subjected to centrifugation at $10,000 \times \mathrm{g}$ for 30 minutes at $4{ }^{\circ} \mathrm{C}$. Supernatants were then transferred into fresh $2 \mathrm{ml}$ microcentrifuge tubes (without cellular debris), followed by the addition of $200 \mu \mathrm{l}$ of chloroform ( $200 \mu \mathrm{l}$ chloroform / $\mathrm{ml}$ of Trizol). Then the mixtures were vortexed thoroughly before centrifugation again at $10,000 \times \mathrm{g}$ for 20 minutes at $4{ }^{\circ} \mathrm{C}$. The top clear aqueous phase was transferred into a $1.5 \mathrm{ml}$ microcentrifuge tube for RNA precipitation, which was performed by the "salting out" method of the addition of $250 \mu \mathrm{l} 0.8 \mathrm{M}$ sodium citrate and 1.2 sodium chloride, and $250 \mu \mathrm{l}$ of $100 \%$ isopropanol. Mixtures were vortexed thoroughly and stored at $-20{ }^{\circ} \mathrm{C}$ overnight to allow RNA precipitation. On the next day, the RNA was pelleted by centrifugation at $10,000 \times \mathrm{g}$ for 30 minutes at $4{ }^{\circ} \mathrm{C}$ to maintain the integrity of the RNA pellet. Ethanol was removed and the pellets were allowed to air dry (10-15 minutes). RNA pellets were resuspended in $25 \mu \mathrm{l}$ of $1 \mathrm{mM}$ sodium citrate $(\mathrm{pH}=6.4)$ followed by incubation at $55^{\circ} \mathrm{C}$ for 5 minutes to aid in dissolving the RNA.

\section{Qualification and Quantification of isolated total RNA}

Sample concentrations and purities were determined by the measurement of absorbance at the wavelength of $260 \mathrm{~nm}$ (A260) and the ratio of A260/ A280 respectively. $2 \mu$ of total RNA sample was placed carefully onto the quartz spot of a NanoQuant plate and which was immediately inserted into a microplate reader (infinite M200 pro plate reader) and analyzed by default software settings ( $i$-control software, Tecan). The ratios of A260/A280 obtained form 16 samples were in between 1.36 to 2.15 , and the sample concentrations were used to calculate the amount of samples that required to load in agarose gel-electrophoresis for the detection of total RNA integrity. Ethidium bromide was used as a fluorescent RNA stain and the staining intensity of the two major ribosomal RNA ( $r R N A$ ) bands, $18 \mathrm{~S}$ and $28 \mathrm{~S}$, represented the quality of total RNA. Four samples (one from each stage) with A260/A280 ratio from 1.55 to 2.15 and with intensive $18 \mathrm{~S}$ and $28 \mathrm{~S}$ rRNA bands were selected for reverse transcription (RT) and polymerase chain reaction (PCR).

\section{Deoxyribonuclease (DNase) treatment and Reverse transcription (RT)}

Prior to RT-PCR, genomic DNA contaminants must be removed from RNA samples. $15 \mu$ of sample was transferred into a fresh $0.2 \mathrm{ml} \mathrm{PCR}$ tube and treated with $1 \mu \mathrm{l}$ of $10 \mathrm{X}$ reaction buffer with $\mathrm{MgCl} 2$, and $1 \mu \mathrm{l}$ of DNase I, RNase-free (\#EN0521)*. The mixtures were incubated at $37^{\circ} \mathrm{C}$ for 30 minutes, followed by adding $1 \mu \mathrm{l}$ of $50 \mathrm{mM}$ EDTA and incubated again at $65^{\circ} \mathrm{C}$ for 10 minutes. The treated total RNA was used as a template for reverse transcription to first strand cDNA. $10 \mu l$ sample was transferred into a fresh $0.2 \mathrm{ml} \mathrm{PCR} \mathrm{tube} \mathrm{and} \mathrm{mixed} \mathrm{with} 1 \mu \mathrm{l}$ of Oligo (dT) 18 primers and $1 \mu \mathrm{l}$ of random primers. The mixtures were centrifuged briefly before incubation at $65^{\circ} \mathrm{C}$ for 5 minutes, and after incubation the samples were chilled on ice immediately. $4 \mu \mathrm{l}$ of $5 \mathrm{X}$ reaction buffer, $1 \mu \mathrm{l}$ of RiboLock RNase inhibitor $(20 \mathrm{U} / \mu \mathrm{l}), 2 \mu \mathrm{l}$ of $10 \mathrm{mM}$ dNTP Mix, and $1 \mu \mathrm{l}$ of RevertAid MMuLVRT $(200 \mathrm{U} / \mu \mathrm{l})$ were added in order then the mixtures were centrifuged briefly followed by incubation at $42{ }^{\circ} \mathrm{C}$ for 60 minutes and the reaction was terminated by incubation at $70{ }^{\circ} \mathrm{C}$ for 5 minutes.

\section{Primer design and Polymerase Chain Reaction (PCR)}

Gene specific primers to BMP-2, BMP-4, and BMPR-2 were designed using PrimerQuest software (IDT) and gene sequences mined out of the recently assembled draft genome of Austrofundulus limnaeus. Primer sequences were confirmed as unique to the genes of interest by alignment to known nucleotide sequences in the NCBI Genbank nonredundant database using the BLAST 
search tool. Pairs of primers (forward and reverse) were ordered from IDT. Primers were resuspended in TBE buffer as $100 \mu \mathrm{M}$ stocks were diluted to $10 \mu \mathrm{M}$ with $\mathrm{dH} 2 \mathrm{O}$ and stored at -20 ${ }^{\circ} \mathrm{C}$ for PCR.

The first strand cDNA obtained from RT was used directly in PCR. The sequences of primers used for PCR were: BMP-2 (forward), 5'- AAG GCC AGC ACG ATT AGA AG - 3'; BMP-2 (reverse), 5' - ATC CAG GTA GAG CAA GGA AAT G - 3'; BMP-4 (forward), 5' - GGT ACC TGA AGA AGG GAA GAA G -3'; BMP-4 (reverse), 5'- TGA CCG AAA GTA ACC AGA AGA G - 3'; BMPR-2 (forward), 5'CAG AGT ACC AGA TGG CCT TTC -3'; BMPR-2 (reverse), 5'- CAG GTT CTT GTC CAC CTC TTT - 3'. PCR reactions were carried out in $50 \mu$ reactions containing $10 x$ Taq buffer $(5 \mu \mathrm{l}), 10 \mathrm{mM}$ dNTP's $(1 \mu \mathrm{l})$, DNase free $\mathrm{H} 2 \mathrm{O}(40.75 \mu \mathrm{l})$ and Taq DNA polymerase $(0.25 \mu \mathrm{l})$. Thermal cycling was initiated by heating at $94{ }^{\circ} \mathrm{C}$ for 5 minutes to active polymerase and denature the DNA, followed by 40 cycles of denaturation at $94{ }^{\circ} \mathrm{C}$ for 20 seconds, annealing at $60{ }^{\circ} \mathrm{C}$ for 20 seconds, and elongation at $68^{\circ} \mathrm{C}$ for 1 minute. The final products obtained from RT-PCR were analyzed using $1.2 \%$ agarose gel electrophoresis.

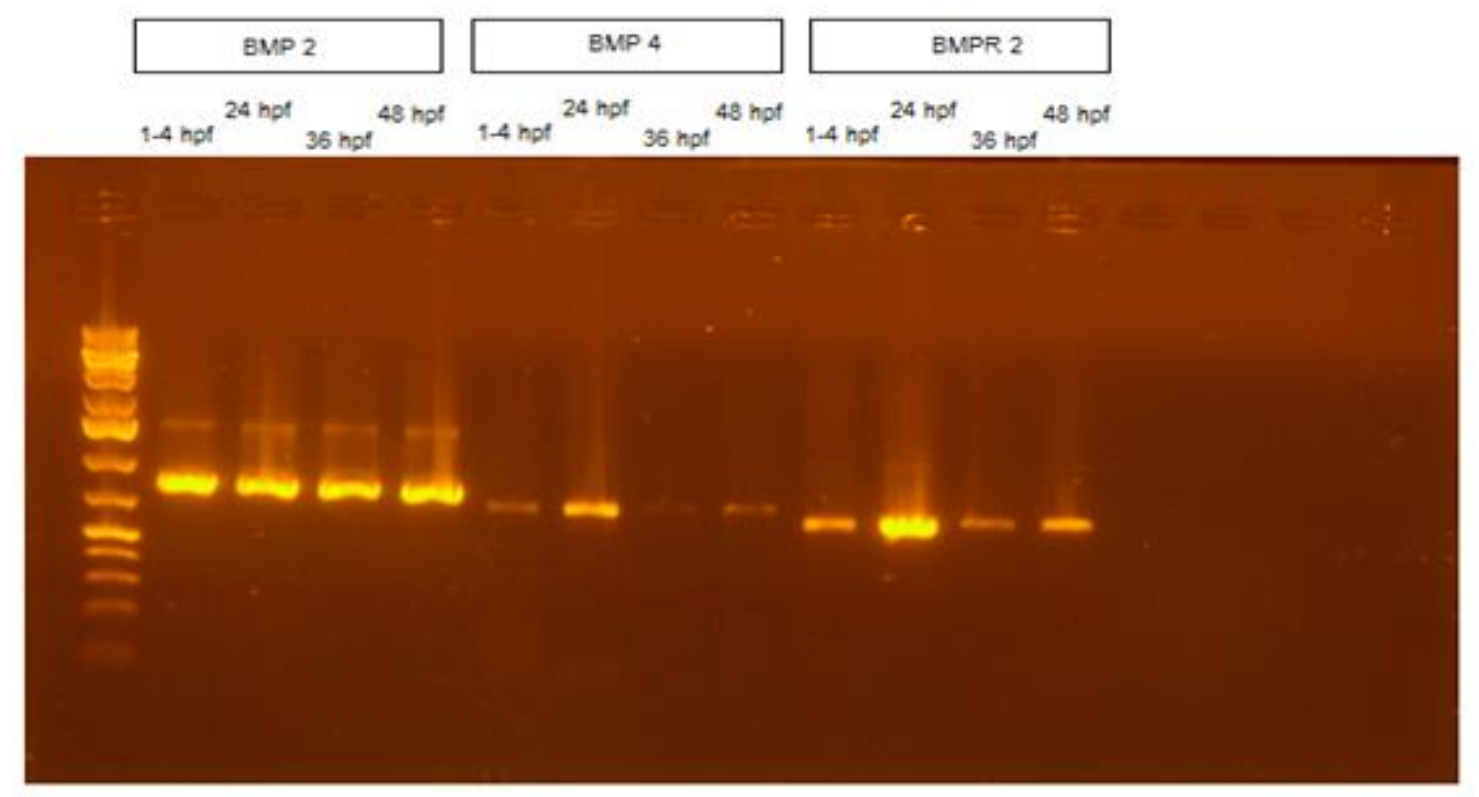

Figure 1. An agarose gel of RT-PCR products, BMP2, BMP4, and BMPR2, in four different developmental stages in $A$. limnaeus embryos. Size marker: $1 \mathrm{~kb}$ plus DNA ladder: 20000, 10000, 7000, 5000, 4000, 3000, 2000, 1500, 1000, 700, $500,400,300,200$ and 75 bp from top to bottom. Amplicon length of BMP2 was 870 bp, BMP4 was 735 bp, and BMPR2 was $680 \mathrm{bp}$.

\section{Results}

Partial mRNA sequences of interest were amplified by RT- PCR and the results revealed the presence and differential expression of BMP-2, BMP-4 and BMPR-2 transcript at 1-4 hpf, 24 hpf, $36 \mathrm{hpf}$, and $48 \mathrm{hpf}$ of $A$. limnaeus embryos. High BMP-2 expression was detected in all four stages. Compared to DNA ladder, four intensive bands appeared in between 700 to $1000 \mathrm{bp}$ in the agarose gel analysis and the expected amplicon length of BMP-2 produced from RT-PCR was 
870 bp (see Fig 1). In BMP-4 and BMPR-2, strong expression was detected in embryos at 24 hpf while relatively weak expression was detected in embryos at the other stages. The expected amplicon length of BMP-4 and BMPR-2 were 735 bp and 680 bp respectively. Four different intensity bands appeared at 700 bp in BMP-4, and in BMPR-2 the bands appeared right below $700 \mathrm{bp}$.

\section{Discussion}

BMPs play important roles in embryogenesis especially during early developmental stages. The concentration gradient of BMPs and BMP antagonists control correct dorsal-ventral patterning in Xenopus and zebrafish embryos (De Robertis and Kuroda, 2004; Zhang et al, 2007). BMP antagonists directly bind to BMPs preventing them from binding to their cognate receptors thus inhibit ventralizing activities (Kondo, 2007). Overexpression of BMP antagonists would cause dorsalization in zebrafish embryos (Kondo, 2007). The developmental patterns of annual killifish embryos are unique compared to other fish (Wourms, 1972a; Wourms, 1972b; Wourms, 1972c). Diapause II and III are frequently observed in the lab population of $A$. limnaeus, yet the underlying molecular mechanisms that regulate diapause is currently unknown. In zebrafish, RT- PCR detected the expressions of three BMP genes, BMP-2a, BMP-2b and BMP-4, in embryos at 4, 8, 11 and 36 hours after fertilization (Martinez-Barbera et al, 1997). In the present paper, the data obtained from RT-PCR also shown BMP-2 and BMP-4 were expressed in A. limnaeus embryos at 1-4 hpf, 24 hpf, $36 \mathrm{hpf}$ and $48 \mathrm{hpf}$. Conversely, the gene expressions of BMP antagonists, noggin, chordin and follistatin, were not the same in $A$. limnaeus and zebrafish during development (Wagner and Podrabsky, 2015). The continued expression of chordin throughout early-embryonic development in A. limnaeus was in contrast to zebrafish (Wagner and Podrabsky, 2015). If the maternally packaged chordin and noggin mRNAs lead to expression of active proteins, then the findings above suggest that the extracellular gradients of free BMP-2 and BMP-4 signaling may be disrupted in early stages of $A$. limnaeus embryos compared to zebrafish, and this may contribute to the unusual developmental pathway in $A$. limnaeus embryos. Wholemount in situ hybridization can be used to further refine the mRNA expression of these genes in specific locations in $A$. limnaeus embryos. Also, further studies on other BMPs (BMP-1, $-3,-5$ and -7 ) and BMP receptors (BMPR-1a and BMPR-1b) may provide more information about the mechanisms by which BMP signaling control the unusual developmental pattern in $A$. limnaeus or if there is any relationship between diapause and the BMP signaling pathway. 


\section{Work Cited}

Chen, D., Zhao, M., \& Mundy, G. R. (2004). Bone morphogenetic proteins. Growth Factors (Chur, Switzerland), 22(4), 233241. doi: $10.1080 / 08977190412331279890$

De Robertis, EM. and Sasai, Y. (1996) A common plan for dorsoventral patterning in Bilateria. Nature 380, 37-40.

De Robertis, E. M., \& Kuroda, H. (2004). Dorsal-Ventral Patterning and Neural Induction in Xenopus Embryos. Annual Review of 'Cell and Developmental Biology, 20, 285-308. http://doi.org/10.1146/annurev.cellbio.20.011403.154124

Hrbek, T. and Larson, A. (1999). The evolution of diapause in the killifish family Rivulidae (Atherinomorpha, Cyprinodontiformes): a molecular phylogenetic and biogeographic perspective. Evolution 53, 1200-1216.

Hrbek, T., D. C. Taphorn and J. E. Thomerson (2005). Molecular phylogeny of Austrofundulus Myers (Cyprinodontiformes: Rivulidae), with revision of the genus and the description of four new species. Zootaxa 825, 1-39.

Kimmel, C.B., Warga, R.M. and Schilling. T.F. (1990) Origin and organization of the zebrafish fate map. Development 108.581-594.

Kondo, M. (2007). Bone morphogenetic proteins in the early development of zebrafish. FEBS Journal, 274 (12), $2960-$ 2967. http://doi.org/10.1111/j.1742-4658.2007.05838.x

Larraín, J., D. Bachiller, B. Lu, E. Agius, S. Piccolo and E. De Robertis (2000). BMP-binding modules in chordin: a model for signalling regulation in the extracellular space. Development 127(4), 821-830.

Liu, A. and L. Niswander (2005). Bone morphogenetic protein signalling and vertebrate nervous system development. Nature Reviews Neuroscience 6(12), 945-954.

Martínez-Barberá, J. P., Toresson, H., Da Rocha, S., \& Krauss, S. (1997). Cloning and expression of three members of the zebrafish Bmp family: Bmp2a, Bmp2b and Bmp4. Gene, 198(1-2), 53-59. http://doi.org/10.1016/S0378$1119(97) 00292-8$

Moos, Jr., M., Wang, S. and Krinks, M. (1995) Anti-dorsalizing morphogenetic protein is a novel TGF-beta homolog expressed in the Spemann organizer. Development 121,4293-4230.

Murphy, W. J. and Collier, G. E. (1997). A molecular phylogeny for aplocheiloid fishes (Atherinomorpha, Cyprinodontiformes): the role of vicariance and the origins of annualism. Molecular Biology and Evolution 14, 790799.

Nikaido, M., Tada, M., Saji, T., \& Ueno, N. (1997). Conservation of BMP signaling in zebrafish mesoderm patterning. Mechanisms of Development, 61(1-2), 75-88. doi:10.1016/S0925-4773(96)00625-9

Podrabsky, J. E. (1999). Husbandry of the annual killifish Austrofundulus limnaeus with special emphasis on the collection and rearing of embryos. Environmental Biology of Fishes 54, 421-431.

Podrabsky, J. E. and Hand, S. C. (1999). The bioenergetics of embryonic diapause in an annual killifish, Austrofundulus limnaeus. Journal of Experimental Biology 202, 2567-2580.

Podrabsky, J. E., Hrbek, T. and Hand, S. C. (1998). Physical and chemical characteristics of ephemeral pond habitats in the Maracaibo basin and Llanos region of Venezuela. Hydrobiologia 362, 67-78.

Podrabsky, J. E., Garrett, I. D. F., \& Kohl, Z. F. (2010). Alternative developmental pathways associated with diapause regulated by temperature and maternal influences in embryos of the annual killifish Austrofundulus limnaeus. The Journal of Experimental Biology 213(19), 3280-3288. doi:10.1242/jeb.045906

Re'em-Kalma, Y., Lamb, T. and Frank, D. (1995). Competition between noggin and bone morphogenetic protein 4 activities may regulate dorsalization during Xenopus development. Proceedings of the National Academy of Sciences of the USA 92, 12141-12145.

Nikaido, M., M. Tada, T. Saji and N. Ueno (1997). Conservation of BMP signaling in zebrafish mesoderm patterning. Mechanisms of Development 61(1), 75-88.

von der Hardt, S., J. Bakkers, A. Inbal, L. Carvalho, L. Solnica-Krezel, C.-P. Heisenberg and M. Hammerschmidt (2007). The Bmp gradient of the zebrafish gastrula guides migrating lateral cells by regulating cell-cell adhesion. Current Biology 17(6), 475-487.

Wagner, J. and J. Podrabsky (2015). Gene expression patterns that support novel developmental stress buffering in embryos of the annual killifish Austrofundulus limnaeus. EvoDevo 6, 1-13.

Winnier, G., M. Blessing, P. A. Labosky and B. Hogan (1995). Bone morphogenetic protein-4 is required for mesoderm formation and patterning in the mouse. Genes \& Development 9(17), 2105-2116.

Wourms, J. P. (1972). The developmental biology of annual fishes III. Pre-embryonic and embryonic diapause of variable duration in the eggs of annual fishes. Journal of Experimental Zoology 182(3), 389-414.

Wourms, J. P. (1972b). The developmental biology of annual fishes. II. Naturally occurring dispersion and reaggregation of blastomers during the development of annual fish eggs. Journal of Experimental Zoology 182, 169-200.

Wourms, J. P. (1972c). The developmental biology of annual fishes III. Pre-embryonic and embryonic diapause of variable duration in the eggs of annual fishes. Journal of Experimental Zoology 182, 389-414.

Zhang, Y.-T., Lander, A. D., \& Nie, Q. (2007). Computational analysis of BMP gradients in dorsal ventral patterning of the zebrafish embryo. Journal of Theoretical Biology 248(4), 579-589. http://doi.org/10.1016/j.jtbi.2007.05.026 